\title{
Deskripsi Kemampuan Penalaran Analogi Siswa Kelas VIII SMP Negeri 2 Gumelar
}

\section{Ditinjau Dari Gender}

\author{
Surya Anding Permadi \\ Program Studi Pendidikan Matematika, Universitas Muhammadiyah Purwokerto \\ surya.anding07@gmail.com
}

\begin{abstract}
ABSTRAK
Penelitian ini bertujuan untuk mendeskripsikan kemampuan penalaran analogi siswa kelas VIII SMP Negeri 2 Gumelar ditinjau dari gendernya. Metode penelitian yang digunakan dalam penelitian ini adalah metode penelitian deskriptif kualitatif. Subjek dalam penelitian ini adalah siswa kelas VIII D SMP Negeri 2 Gumelar yang berjumlah 28 siswa terdiri dari 15 siswa laki-laki dan 13 siswa perempuan. Pengambilan sampel dilakukan menggunakan teknik purposive sampling. Dalam satu kelas dipilih 3 siswa laki-laki dan 3 siswa perempuan yang memiliki komunikasi baik dan kemampuan matematika relatif sama. Pengumpulan data dalam penelitian ini menggunakan tes, wawancara dan dokumentasi. Teknik analisis data yang diguakan meliputi reduksi data, penyajian data dan kesmipulan. Uji validasi yang digunakan adalah triangulasi teknik. Hasil penelitian menunjukan bahwa siswa laki-laki lebih baik kemampuan penalaran analoginya dibandingkan dengan siswa perempuan. Siswa laki-laki sudah menguasai empat komponen kemampuan penalaran analogi yaiut Encoding, Inferring, Mapping dan Applying. Sedangkan, siswa perempuan hanya menguasai tiga komponen kemampuan penalaran analogi yaitu Inferring, Mapping dan Applying.
\end{abstract}

Kata kunci : Encoding, Gender, Kemampuan Penalaran Analogi

\begin{abstract}
This study aims to describe the analytical reasoning ability of Grade VIII students of SMP Negeri 2 Gumelar in terms of gender. The research method used in this research is descriptive qualitative research method. The subjects in this study were students of class VIII D of SMP Negeri 2 Gumelar, totaling 28 students consisting of 15 male students and 13 female students. Sampling was done using purposive sampling technique. In one class, 3 male and 3 female students were selected who had good communication and relatively similar mathematical abilities. Data collection in this study used tests, interviews and documentation. Data analysis techniques used include data reduction, data presentation and conclusion. The validation test used is technical triangulation. The results showed that male students had better analytical reasoning abilities compared to female students. Male students have mastered the four components of analogy reasoning ability encompassing Encoding, Inferring, Mapping and Applying. Meanwhile, female students only mastered the three components of analogy reasoning ability namely Inferring, Mapping and Applying.
\end{abstract}

Keywords: Encoding, Gender, Analytical Reasoning Ability

\section{Pendahuluan}

Matematika merupakan ilmu yang berperan sangat penting dalam kehidupan manusia dan sangat berkaitan dengan ilmu pengetahuan lainnya. Matematika adalah ilmu dasar yang mendasari ilmu pengetahuan lain (Hariwijaya, 2009). Oleh karena itu, matematika perlu diberikan kepada peserta didik mulai dari sekolah dasar untuk membekali peserta didik dengan kemampuan-kemampuan matematis sampai dengan perguruan tinggi. Hal tersebut membuktikan bahwa betapa pentingnya matematika, sehingga pelajaran matematika selalu ada dalam setiap jenjang pendidikan.

NCTM (2000) menyebutkan bahwa pembelajaran matematika adalah proses membelajarkan peserta didik agar memiliki kemampuan untuk berpikir matematis serta memiliki pengetahuan dan keterampilan dasar matematika. NCTM (2000) menetapkan lima standar kemampuan matematis yang harus dimiliki oleh siswa yaitu kemampuan pemecahan masalah (problem solving), kemampuan komunikasi (communication), kemampuan koneksi (conection), 
kemampuan penalaran (reasoning), dan kemampuan representasi (representation). Salah satu tujuan yang ingin dicapai dalam pembelajaran matematika adalah kemampuan penalaran. Dalam hal ini, siswa diharapkan mampu memahami konsep-konsep yang terdapat dalam pembelajaran matematika. Akan tetapi, saat ini masih banyak siswa yang tergolong belum mampu dalam memahami konsep-konsep yang terdapat dalam pembelajaran matematika dengan baik. Hal tersebut dikarenakan sebagian besar konsep yang terdapat dalam pembelajaran matematika merupakan konsep yang bersifat abstrak, sehingga sulit dipahami oleh siswa. Maka dari itu, diperlukan suatu kemampuan matematis yang dapat membantu siswa dalam memahami konsep-konsep matematika. Salah satu kemampuan matematis tersebut yaitu kemampuan penalaran matematis.

Soemarmo \& Hendriana (2014) menyatakan bahwa penalaran merupakan unsur yang penting dalam pemahaman matematis, mengeksplorasi ide, memperkirakan solusi, dan menerapkan ekspresi matematika yang relevan, serta memahami bahwa matematika itu bermakna dan matematika itu sesuatu hal yang logis. Penalaran dibagi menjadi dua yaitu penalaran induktif dan penalaran deduktif. Ditinjau dari karakteristik penarikan kesimpulannya, penalaran induktif terdiri dari penalaran transduktif, penalaran analogi, penalaran generalisasi, memperkirakan jawaban, solusi atau kecenderungan, dan menggunakan pola hubungan untuk menganalisis situasi dan menyusun konjektur. Dari kelima karakteristik penarikan kesimpulan di atas, penalaran analogi merupakan salah satu kemampuan penalaran yang penting untuk dikembangkan.

Berbicara tentang analogi menurut Soekadijo (1999), analogi adalah berbicara tentang dua hal yang berlainan dan dua hal yang berlainan tersebut diperbandingkan, jika dalam perbandingan yang diperhatikan persamaannya saja tanpa melihat perbedaan maka timbullah analogi. Dalam melakukan perbandingan kita mencari persamaan dan perbedaan antara keduanya. Jika dalam perbandingan itu orang hanya memperhatikan persamaannya saja tanpa melihat perbedaannya maka timbullah analogi persamaan (keserupaan) diantara dua hal yang berbeda, dan selanjutnya akan ditarik suatu kesimpulan atas dasar keserupaan tadi. Menurut Soemarmo (2015) penalaran analogi adalah penarikan kesimpulan berdasarkan keserupaan data atau proses. Menurut Shadiq (2013) menyatakan bahwa analogi merupakan membandingkan dua hal yang berbeda dengan hanya memperhatikan persamaanya saja dan tidak memperhatikan perbedaannya untuk kemudian ditarik kesimpulannya. Menurut Holyoak (2012), analogi digunakan untuk memecahkan masalah dengan cara siswa pada saat menyelesaiakan masalah mereka akan menerapkan pengetahuan yang sudah diketahui untuk memecahkan masalah baru.

Berdasarkan penjelasan di atas, kemampuan penalaran analogi merupakan proses berpikir siswa dalam mencari kemiripan dari dua hal yang berbeda dan menarik kesimpulan atas dasar kemiripan tersebut. Penalaran analogi digunakan untuk meningkatkan pemahaman siswa dengan membandingkan konsep-konsep baru dan konsep-konsep yang sudah dipelajari. Maka dari itu, kurangnya kemampuan penalaran analogi dapat mempengaruhi kemampuan siswa dalam menyelesaikan masalah matematika.

Dalam menyelesaikan masalah, terdapat beberapa faktor yang dapat menyebabkan adanya perbedaan kemampuan penalaran analogi yang dimiliki oleh siswa. Salah satu faktor yang yang mempengaruhi adalah perbedaan gender. Menurut Santrock (2010) menyatakan bahwa dalam beberapa analisis, anak laki-laki lebih bagus dalam matematika dibandingkan perempuan dan ini telah lama menjadi perhatian. Menurut Slavin (2008) menyatakan bahwa 
dalam ringkasan 20 studi besar oleh Kim menemukan bahwa laki-laki memperoleh nilai yang lebih baik daripada wanita dalam matematika, sedangkan kebalikannya berlaku untuk ujian bahasa Inggris. Lebih lanjut Slavin (2008) mengatakan bahwa pada umumnya studi menemukan bahwa laki-laki memperoleh nilai yang lebih tinggi daripada wanita dalam ujian pengetahuan umum, penalaran, mekanis, dan rotasi mental; wanita memperoleh nilai yang lebih tinggi dalam pengukuran bahasa, termasuk penilaian membaca dan menulis. Menurut Susento (2002:51) perbedaan gender tidak hanya berakibat pada perbedaan kemampuan dalam matematika saja, tetapi cara dalam memperoleh pengetahuan matematika juga terkait dengan perbedaan gender. Berdasarkan pendapat-pendapat yang dikemukakan oleh para ahli tersebut, maka terkait dengan kemampuan penalaran analogi antara siswa laki-laki dan perempuan pasti akan berbeda hasilnya.

SMP Negeri 2 Gumelar merupakan sekolah yang beralamat di Jalan Raya Paningkaban Desa Paningkaban Kecamatan Gumelar Kabupaten Banyumas. Proses pembelajaran di sekolah ini menggunakan Kurikulum 2013 (K-13). Berdasarkan hasil wawancara dengan guru matematika SMP Negeri 2 Gumelar, kendala dalam pembelajaran matematika di kelas adalah adanya sebagian siswa yang merasa bingung dengan permasalahan yang lebih kompleks dan hanya mampu menyelesaikan permasalahan yang sederhana sesuai contoh yang diberikan, meskipun permasalahan tersebut memiliki persamaan konsep antara keduanya. Hal ini berkaitan dengan kemampuan analogi yang dimiliki oleh siswa. Selain itu, menurut guru matematika juga menyampaikan bahwa ada perbedaan kemampuan matematis antara siswa laki-laki dan perempuan di SMP Negeri 2 Gumelar. Oleh karena itu, peneliti tertarik untuk mengetahui atau melihat bagaimana kemampuan penalaran analogi matematis siswa jika ditinjau dari gender di SMP Negeri 2 Gumelar.

Agar penelitian ini dapat terarah dan mendalam serta tidak terlalu luas jangkauannya, maka penelitian ini terbatas pada bagaimana kemampuan penalaran analogi siswa kelas VIII SMP Negeri 2 Gumelar ditinjau dari gender. Sedangkan, Tujuan dari penelitian ini yaitu untuk mendeskripsikan kemampuan penalaran analogi siswa kelas VIII SMP Negeri 2 Gumelar ditinjau dari gender.

\section{Metode Penelitian}

Penelitian ini dilaksanakan di SMP Negeri 2 Gumelar, pada semester genap tahun pelajaran 2018/2019. Subjek penelitian ini adalah siswa kelas VIII SMP Negeri 2 Gumelar tahun ajaran 2018/2019. Teknik pengambilan sampel yang digunakan adalah teknik purposive sampling yaitu proses pengambilan sampel berdasarkan pertimbangan tertentu (Sugiyono, 2013). Pertimbangan yang dipilih dalam penelitian ini adalah hasil dari tes kemampuan penalaran analogi. Jenis penelitian yang digunakan dalam penelitian ini adalah penelitian deskriptif kualitatif yaitu penelitian yang menggunakan data kualitatif dan dideskripsikan untuk menghasilkan gambaran yang jelas dan terperinci mengenai kemampuan penalaran analogi ditinjau dari perbedaan gender siswa kelas VIII SMP Negeri 2 Gumelar.

\section{Hasil dan Pembahasan}

Berdasarkan data yang diperoleh baik data hasil tes kemampuan analogi maupun wawancara serta hasil pemaparan triangulasi, peneliti menyimpulkan penalaran analogi siswa ditinjau dari gender sebgai berikut : 
Tabel 1. Deskripsi Kemampuan Penalaran Analogi Siswa ditinjau dari Gender

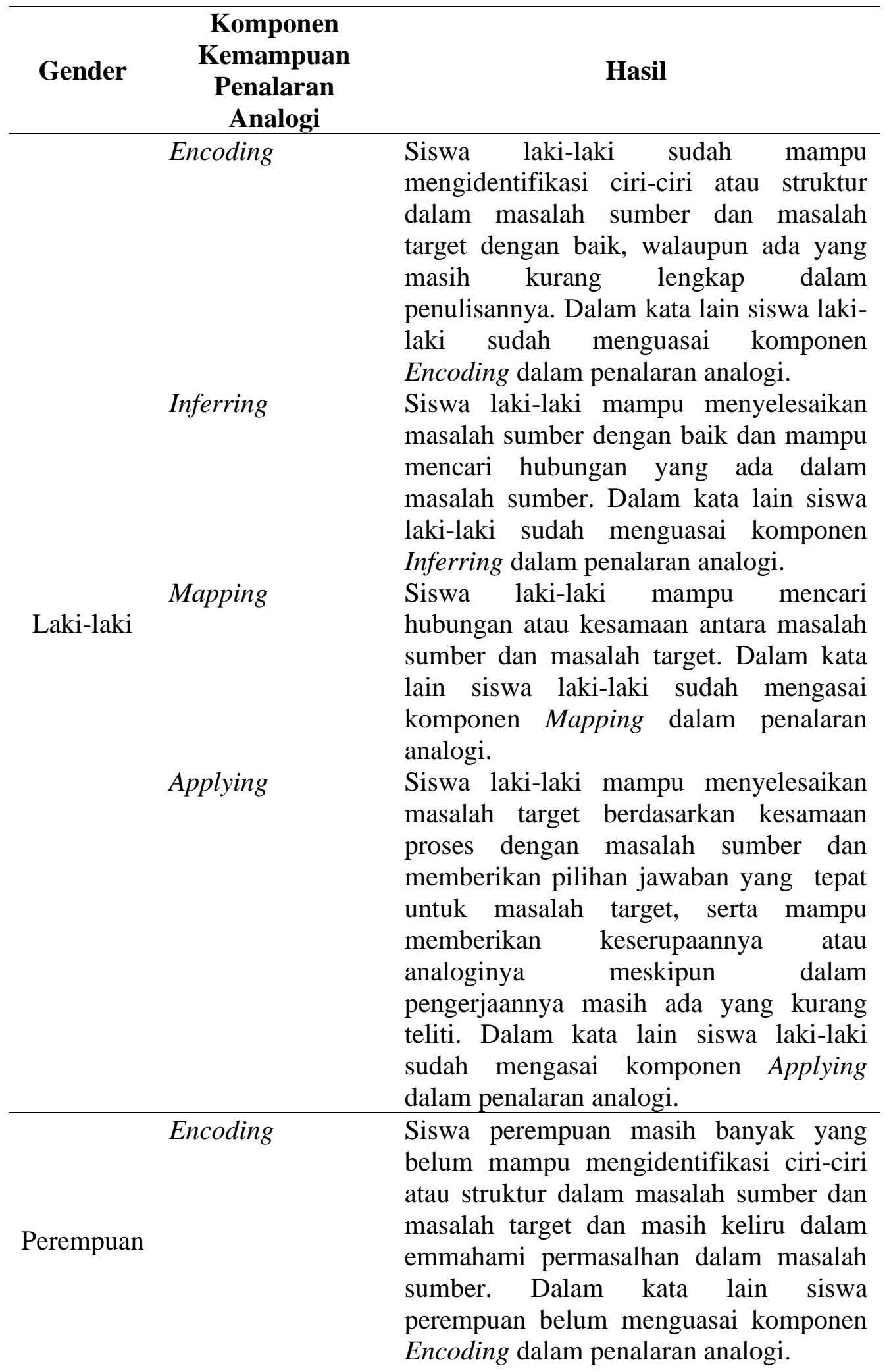




$\begin{array}{ll}\text { Inferring } & \text { Siswa perempuan mampu menyelesaikan } \\ & \text { masalah sumber dengan baik dan mampu } \\ & \text { mencari hubungan yang ada dalam } \\ & \text { masalah sumber. Dalam kata lain siswa } \\ & \text { perempuan sudah menguasai komponen } \\ & \text { Inferring dalam penalaran analogi. } \\ & \text { Siswa perempuan mampu mencari } \\ & \text { hubungan atau kesamaan antara masalah } \\ \text { Mapping } & \text { sumber dan masalah target. Dalam kata } \\ & \text { lain siswa perempuan sudah mengasai } \\ & \text { komponen Mapping dalam penalaran } \\ & \text { analogi. } \\ & \text { Siswa perempuan mampu menyelesaikan } \\ & \text { masalah target berdasarkan kesamaan } \\ \text { proses dengan masalah sumber dan } \\ \text { memberikan pilihan jawaban yang tepat } \\ \text { untuk masalah target, serta mampu } \\ \text { memberikan keserupaannya atau } \\ \text { analoginya meskipun dalam } \\ \text { pengerjaannya masih ada yang kurang } \\ \text { teliti. Dalam kata lain siswa perempuan } \\ \text { sudah mengasai komponen Applying } \\ \text { dalam penalaran analogi. }\end{array}$

Berikut pembahasan mengenai kemampuan penalaran analogi siswa kelas VIII SMP Negeri 2 Gumelar ditinjau dari gender berdasarkan hasil tabel 1 di atas.

\section{Siswa Laki-laki}

Berdasarkan hasil tes dan wawancara, didapatkan bahwa kemampuan penalaran analogi yang dimiliki siswa laki-laki seperti yang pada tabel berikut :

Tabel 2. Kemampuan Penalaran Analogi Siswa Laki-laki

\begin{tabular}{cccccc}
\hline \multirow{2}{*}{$\begin{array}{c}\text { Soal } \\
\text { Nomor }\end{array}$} & \multirow{2}{*}{ Subjek } & \multicolumn{4}{c}{ Komponen Penalaran Analogi } \\
\cline { 3 - 6 } 1 & Encoding & Inferring & Mapping & Applying \\
\hline \multirow{6}{*}{2} & $\checkmark$ & $\checkmark$ & $\checkmark$ & $\checkmark$ \\
& SL1 & $\checkmark$ & $\checkmark$ & $\checkmark$ & $\checkmark$ \\
& SL2 & $\checkmark$ & - & $\checkmark$ & $\checkmark$ \\
& SL1 & $\checkmark$ & $\checkmark$ & - & - \\
& SL2 & $\checkmark$ & $\checkmark$ & $\checkmark$ & $\checkmark$ \\
& SL3 & - & $\checkmark$ & - & - \\
& SL1 & $\checkmark$ & $\checkmark$ & - & - \\
& SL2 & $\checkmark$ & $\checkmark$ & $\checkmark$ & $\checkmark$ \\
& SL3 & $\checkmark$ & $\checkmark$ & $\checkmark$ & $\checkmark$ \\
\hline
\end{tabular}

\section{Encoding (Pengkodean)}

Berdasarkan tabel 2 dapat dilihat bahwa siswa laki-laki secara umum sudah menguasai komponen Encoding dalam penalaran analogi. Hal tersebut menunjukkan bahwa siswa laki-laki secara umum sudah mampu mengidentifikasi ciri-ciri atau struktur masalah sumber dan masalah target kedalam simbol matematis. Hal tersebut ditunjukkan dengan hasil tes penalaran analogi dan wawancara yang lebih mendalam terhadap subjek laki-laki tersebut. Pada soal nomor 1, siswa laki-laki sudah 


\section{AlphaMath \\ Journal of Mathematics Education, 5(2) November 2019}

menuliskan dengan baik ciri-ciri atau struktur dalam masalah sumber dan masalh target baik apa yang diketahui dan apa yang ditanyakan. Pada soal nomor 2, subjek laki-laki masih terdapat kekeliruan dalam menuliskan hal yang ditanyakan dalam masalah sumber dan ada juga yang tidak lengkap menuliskan apa saja yang diketahui dalam masalah sumber dan masalah target. Namun ada subjek siswa laki-laki yang sudah baik dan benar dalam mengidentifikasi ciri-ciri atau struktur masalah sumber dan masalah target pada nomor 2. Pada soal nomor 3, subjek siswa laki-laki sudah menuliskan dengan baik ciri-ciri atau struktur masalah sumber dan masalah target dengan baik.

\section{Inferring (Penyimpulan)}

Selain komponen Encoding, siswa laki-laki juga sudah menguasai komponen yang kedua dalam penalaran analogi yaitu Inferring. Subjek siswa laki-laki sudah mampu menyelesaikan masalah sumber dengan baik dan mampu mengetahui hubungan apa yang ada dalam masalah sumber. Berdasarkan tabel 2 dapat dikatakan bahwa subjek siswa laki-laki sudah menguasai komponen Inferring untuk nomor 1, nomor 2 dan nomor 3 .

\section{Mapping (Pemetaan)}

Untuk komponen penalaran analogi yang ketiga yaitu Mapping, siswa laki-laki sudah mampu mencari hubungan atau kesamaan yang ada antara masalah sumber dengan masalah target. Berdasarkan table 2 untuk nomor 1 subjek laki-laki sudah mampu mencari hubungan atau kesamaan yang ada dalam masalah sumber dan masalah target. Sedangkan untuk nomor 2 dan nomor 3 masih ada siswa laki-laki yang belum bisa mencari hubungan antara masalah sumber dan masalah target tersebut.

\section{Applying (Penerapan)}

Pada komponen penalaran analogi yang keempat yaitu Applying, secara umum siswa laki-laki sudah mampu menyelesaikan masalah target dan memberikan pilihan jawaban dengan benar serta mampu menuliskan keserupaan atau analoginya. Namun ada subjek yang masih salah dalam menyelesaikan. Hal ini dikarenakan subjek tersebut belum bisa mencari hubungan yang ada dalam masalah sumber dan masalah target (Mapping), sehingga dalam penyelesaian masalah target subjek tidak sempurna bahkan ada yang salah.

Namun secara keseluruhan subjek siswa laki-laki sudah menguasai keempat komponen penalaran analogi yaitu Encoding, Inferring, mapping dan Applying. Walaupun siswa laki-laki sudah menguasai keempat komponen tersebut, tetapi dalam penulisannya masih ada beberapa subjek yang belum lengkap dalam menuliskan struktur-struktur yang ada dalam masalah sumber dan masalah target. Dalam menyelesaikan masalah sumber dan masalah target juga terdapat penulisan kurang lengkap, misalnya ketika soal nomor 2. Dalam soal nomor 2 terdapat volume air 360 dan volume bola 90 , tiba-tiba dalam jawaban siswa laki-laki langung tertulis " $v t=$ 450" yang maksudnya adalah volume total yang didapatkan dari volume air + volume bola. Hal ini terkait dengan sifat gender laki-laki yang cenderung kurang teliti dalam kemampuan menulis dan membaca.

\section{Siswa Perempuan}

Berdasarkan hasil tes dan wawancara dapat disimpulkan bahwa kemampuan penalaran analogi yang dimiliki siswa perempuan sepeti yang pada tabel berikut : 
Tabel 3. Kemampuan Penalaran Analogi Siswa Perempuan

\begin{tabular}{cccccc}
\hline \multirow{2}{*}{$\begin{array}{c}\text { Soal } \\
\text { Nomor }\end{array}$} & \multirow{2}{*}{ Subjek } & \multicolumn{4}{c}{ Komponen Penalaran Analogi } \\
\cline { 3 - 6 } 1 & & Encoding & Inferring & Mapping & Applying \\
\hline \multirow{4}{*}{1} & SP1 & $\checkmark$ & - & $\checkmark$ & $\checkmark$ \\
& SP2 & $\checkmark$ & $\checkmark$ & $\checkmark$ & $\checkmark$ \\
& SP3 & $\checkmark$ & $\checkmark$ & $\checkmark$ & $\checkmark$ \\
& SP1 & - & $\checkmark$ & - & - \\
& SP2 & - & $\checkmark$ & - & - \\
& SP3 & $\checkmark$ & $\checkmark$ & $\checkmark$ & $\checkmark$ \\
& SP1 & - & $\checkmark$ & $\checkmark$ & $\checkmark$ \\
3 & SP2 & $\checkmark$ & - & $\checkmark$ & $\checkmark$ \\
& SP3 & - & $\checkmark$ & - & - \\
\hline
\end{tabular}

\section{Encoding (Pengkodean)}

Berdasarkan tabel 3 dapat dilihat bahwa siswa perempuan secara umum belum menguasai komponen penalaran analogi yang pertama yaitu Encoding. Pada soal nomor 1, nomor 2, dan nomor 3 ada subjek perempuan yang tidak mampu mengidentifikasi ciri-ciri atau struktur masalah dengan baik. Terutama dalam masalah sumber, kebanyakan siswa perempuan menuliskan hal yang diketahui sebagai hal yang ditanyakan. Hal tersebut yang menunjukan bahwa siswa perempuan belum menguasai komponen Encoding. Bahkan pada soal nomor 3, tidak ada satupun siswa perempuan yang mampu mengidentifikasi masalah dengan baik.

\section{Inferring (Penyimpulan)}

Untuk komponen yang kedua dalam penalaran analogi yaitu Inferring, siswa perempuan secara umum dapat dikatakan sudah mampu menguasai komponen Inferring. Hal tersebut menunjukkan bahwa semua subjek siswa perempuan sudah mampu menyelesaikan masalah sumber dengan baik dan mampu mencari hubungan yang ada dalam masalah sumber. Meskipun terdapat subjek siswa perempuan yang belum menguasai komponen Inferring pada nomor 1. Tetapi pada soal nomor 2 dan nomor 3, siswa perempun sudah mampu menyelesaikan dengan baik dan benar bahkan sudah mengetahui hubungan yang ada dalam masalah sumber tersebut.

\section{Mapping (Pemetaan)}

Selain komponen Inferring, siswa perempuan secara umum mampu menguasai komponen yang ketiga yaitu Mapping. Siswa perempuan berarti sudah mampu mencari hubungan atau kesamaan antara masalah sumber dengan masalah target. Untuk soal nomor 1, semua subjek siswa perempuan sudah menguasai Mapping dengan baik. Tetapi pada soal nomor 2 dan nomor 3, ada sedikit kesulitan dalam menemukan kesamaan yang terdapat pada masalah sumber dan masalah target. Selain itu, ada juga yang masih belum percaya kepada diri sendiri bahwa dirinya sendiri sudah mampu menemukan kesamaan tersebut. Namun secara umum, siswa perempuan sudah menguasai komponen yang ketiga dalam penalaran analogi yaitu Mapping.

\section{Applying (Penerapan)}

Pada komponen penalaran analogi yang keempat yaitu Applying, secara umum siswa perempuan sudah mampu menyelesaikan masalah target dan memberikan pilihan jawaban dengan benar serta mampu menuliskan keserupaan atau analoginya. Namun 
ada subjek yang masih salah dalam menyelesaikannya. Hal ini dikarenakan subjek tersebut belum bisa mencari hubungan yang ada dalam masalah sumber dan masalah target (Mapping), sehingga dalam penyelesaian masalah target subjek tidak sempurna bahkan masih ada yang salah. Selain itu, dalam penyelesaian masalah target, siswa perempuan lebih detail menuliskan jawabannya dibandingkan dengan siswa laki-laki.

Namun secara keseluruhan subjek siswa perempuan sudah menguasai komponen penalaran analogi, kecuali dalam komponen yang pertama yaitu Encoding, siswa perempuan belum bisa menguasainya dengan baik. Hal tersebut berarti siswa perempuan hanya menguasai tiga komponen penalaran analogi saja, yaitu Inferring, Mapping dan Applying. Walaupun demikian, siswa perempuan dalam penulisan penyelesaian masalah sumber dan masalah target lebih lengkap dan runtut.

\section{Simpulan}

Berdasarkan hasil pembahasan dekripsi kemampuan penalaran analogi kelas VIII SMP Negeri 2 Gumelar ditinjau dari gender yang telah dilakukan, secara umum dapat disimpulkan bahwa kemampuan penalaran analogi siswa laki-laki lebih unggul atau lebih baik disbanding kemampuan penalaran analogi siswa perempuan. Hal tersebut ditunjukkan berdasarkan hasil penelitian, siswa laki-laki sudah menguasi keempat komponen penalaran analogi yaitu Encodiing, Inferring, Mapping dan Applying. Sedangkan siswa perempuan hanya menguasai tiga komponen kemampuan penalaran analogi yaitu Inferrring, Mapping, dan Applying. Untuk siswa laki-laki, sudah menguasai empat komponen penalaran analogi. Terlihat dari jawaban siswa laki-laki dalam menyelesaikan masalah sumber dan masalah target beserta wawancara yang telah peneiliti lakukan dapat dikatakan sudah menguasai Encoding, Inferrng, Mapping dan Applying. Untuk siswa perempuan, sudah menguasai tiga komponen penalaran analogi. Terlihat dari jawaban siswa perempuan dalam menyelesaikan masalah sumber dan masalah target beserta wawancara yang telah peneiliti lakukan dapat dikatakan sudah menguasai Inferrng, Mapping dan Applying.

\section{Daftar Pustaka}

Hariwijaya. (2009). Meningkatkan Kecerdasan Matematika. Tugu Publisher. Yogyakarta. Holyoak, K. J. (2012). Analogy and Relational Reasoning. Oxford University Press. New York.

Lestari, K. E., \& Yudhanegara, M. R. (2015). Penelitian pendidikan matematika. PT Refika Aditama. Bandung.

Lyn.D. (2014). Mathematical and Analogical Reasoning of Young Leaners. Lawrenc Erlnaum Associates. London.

NCTM. (2000). Standards for School Mathematics, Reston, VA. NCTM. Indonesia.

Novick, L. R., \& J, H. K. (1991). Mathematical Problem Solving by Analogy. Journal of Experimental Psychology, 17(3), 398-415.

Puspitawati, H. (2010). Persepsi Peran Gender Terhadap pekerjaan Domestik dan Publik pada Mahasiswa IPB. Jurnal Studi Gender Dan Anak, 5(1), 17-34.

Rahmawati, D. I., \& Pala, R. H. (2017). Kemampuan Penalaran Analogi dalam Pembelajaran Matematika. Euclide, 4(2), 1-9.

Salmina, M., \& Nisa, S. K. (2008). Kemampuan Penalaran Matematis Siswa Berdasarkan

Gender Pada Materi Geometri. Numeracy, 5(1), 41-48.

Santrock, J. W. (2010). Psikologi Pendidikan. Kencana. Jakarta.

Santrock, J. W. (2014). Psikologi Pendidikan. Salemba Humanika. Jakarta. 
Shadiq, F. (2013). Penalaran dengan Analogi? Pengertiannya dan Mengapa Penting. Widyaiswara PPPPTK Matematika1-7.

Slavin, E. R. (2008). Cooperative Learning Teori Riset dan Praktik. Nusa Media. Bandung. Soekadijo, G. R. (1985). Logika Dasar Tradisional, Simbolik dan Induktif. Gramedia. Jakarta. Soekadijo, G. R. (1999). Logika Dasar Tradisional, Simbolik dan Induktif. Gramedia. Jakarta. Soemarmo, U. (2015). Berpikir dan Disposisi Matematik serta Pembelajarannya. UPI. Bandung.

Soemarmo, U., \& Hendriana, H. (2014). Penilaian Pembelajaran Matematika. PT Refika Aditama. Bandung.

Sugiyono. (2013). Metode Penelitian Pendidikan : Pendekatan Kuantitatif, Kualitatif, dan R $\& D$. Alfabeta. Bandung.

Surna, Pendeirot, I. N., \& Olga, D. (2014). Psikologi Pendidikan 1. Erlangga. Jakarta.

Wedege, T. (2011). Doing gender in mathematics education. Stockhol Universitets Forlag. Stockholm. 